\title{
Common genetic effects on risk-taking preferences and choices
}

\author{
Nicos Nicolaou ${ }^{1} \cdot$ Scott Shane ${ }^{2}$
}

Published online: 9 January 2020

(C) The Author(s) 2020

\begin{abstract}
Although prior research has shown that risk-taking preferences and choices are correlated across many domains, there is a dearth of research investigating whether these correlations are primarily the result of genetic or environmental factors. We examine the extent to which common genetic factors account for the association between general risk-taking preferences and domain-specific risk-taking preferences, and between general risk-taking preferences and risk taking choices in financial investments, stock market participation and business formation. Using data from 1898 monozygotic (MZ) and 1344 same-sex dizygotic (DZ) twins, we find that general risk-taking shares a common genetic component with domain-specific risk-taking preferences and risktaking choices.
\end{abstract}

Keywords Risk taking preferences $\cdot$ Twins $\cdot$ Portfolio choice $\cdot$ risk taking across domains

JEL Classifications D03 · G02 · D81

\section{Introduction}

The description of people as risk-taking or risk-avoiding types is not a rhetorical flourish. Some people regularly speed when driving, take up risky sports, choose financial investments that incur a high chance of loss, and select risky occupations, like starting their own businesses. Others always drive below the speed limit, pick tame

Nicos Nicolaou

Nicos.Nicolaou@wbs.ac.uk

Scott Shane

Scott.Shane@case.edu

1 Warwick Business School, University of Warwick, Coventry CV4 7AL, UK

2 Weatherhead School of Management, Case Western Reserve University, 10900 Euclid Avenue, Cleveland, OH 44106-7235, USA 
leisure activities, pick investments that preserve their capital, and choose stable occupations.

Prior research has shown that preferences for high risk activities tend to be correlated across multiple domains, from financial investments to decisions about health to job choice to leisure activities (Barsky et al. 1997; Beauchamp et al. 2017; Dohmen et al. 2011; Donkers et al. 2001; Ekelund et al. 2005; Halek and Eisenhauer 2001; Zhong et al. 2009a). In addition, prior research has shown that risk-taking preferences are correlated with risk taking choices, such as undertaking entrepreneurship and investing in the stock market (Dohmen et al. 2011).

While academics have long known about these correlations, little research has explored their source. Some researchers have suggested that innate differences may account for at least some part of these correlations, with variation in genetic composition predisposing some people to have more general risk taking preferences, to be more prepared for risk taking in multiple domains and to select higher risk choices than other people (Beauchamp et al. 2017; Dreber et al. 2009).

However, the degree to which the correlation in risk taking behavior across domains is accounted for by genetics has received very little attention because identification is not easy (Karlsson Linnèr et al. 2019). Any observed statistical association between general risk-taking preferences, domain-specific risk taking preferences, and risk taking choices may occur because of genetic factors, environmental factors, or both.

This study uses the natural experiment of twins to identify the extent to which common genetic factors account for the association (i) between general risk-taking preferences and domain-specific risk taking preferences in five domains: car driving, financial matters, sports and leisure, career, and health, (ii) between general risk-taking preferences and approaches taken to financial investments, (iii) between general risktaking and stock market participation, and (iv) between general risk-taking and the choice of entrepreneurship as an occupational choice. Specifically, we examine 1898 monozygotic (MZ) and 1344 same-sex dizygotic (DZ) twins from the United Kingdom, who were surveyed in 2011. By comparing the correlations between different measures for pairs of $\mathrm{MZ}$ and $\mathrm{DZ}$ twins, we can decompose phenotypic correlations into those correlations that occur for genetic and environmental reasons.

We find that a substantive part of the variation in: general risk-taking preference; domain-specific risk taking preferences in the five domains of finance, health, career, driving, and sports and leisure; stock market participation; financial investment choices; and the decision to be self-employed are explained by genetic factors. Moreover, our study indicates that general risk-taking shares a common genetic component with risk taking in the five domains and the three risk-taking choices we examined. These effects persist after separating out the effects of the Big Five personality traits, sensation seeking, age, and gender.

These findings are in line with the work of Beauchamp et al. (2017) who find sizable associations between risk attitudes and investment decisions, personality, smoking, drinking and cognitive ability. Beauchamp et al. (2017) advanced the seminal work of Cesarini et al. (2009) and Cesarini et al. (2010) who had found a genetic predisposition for risk taking and financial decision making. Our paper extends the study of Beauchamp et al. (2017) by investigating the drivers of these associations through examining the genetic covariations between general risk-taking preferences and financial investment choices, domain-specific risk preferences, stock market participation 
and business formation. Our paper also adds to the excellent recent work of Karlsson Linnèr et al. (2019) who conducted a genome-wide association study of over one million individuals and found that general risk tolerance is genetically correlated with risky behaviors including speeding, adventurousness and number of sexual partners.

Our findings have several implications. First, our study contributes to a biosocial perspective on risk taking (Cesarini et al. 2009). Our findings that a genetic predisposition to risk taking preferences and choices exists in many different domains, from financial investment choices to taking career risks, offers a novel explanation for the similarity in risk-taking behavior between parents and children. Children may adopt similar approaches to driving, and choose similar sports, occupations or ways of investing because they share the same genetic composition as their parents, rather than because they learned these preferences and approaches from their parents or because they share a common culture. ${ }^{1}$

Second, our results suggest that people with a greater preference for risk are more likely to undertake risky behaviors because of a common genetic aetiology between general risk-taking preferences and domain-specific risk preferences, between general risk-taking and financial investment choices, between general risk-taking and stock market participation, and between general risk-taking and the choice of entrepreneurship as a career. Different variants of genes predispose people to develop different risk preferences across a variety of settings. These genetically-influenced preferences lead the same people to be disproportionately likely to make risky financial investment choices, participate in the stock market and choose entrepreneurship as an occupation (and make other similar decisions we cannot observe), as they seek to fit their behavioral choices to their innate tendencies.

Third, our study shows that the entire environmental influence in the risk taking behaviors we examined is accounted for by non-shared environmental factors. These results suggest that factors, such as the work environment and work colleagues, are more important for risk taking than shared environmental influences, such as parental upbringing and shared family experiences.

Fourth, our results have important implications for the ability of managers and policy makers to influence human behavior. That ability depends on the levels of genetic and environmental correlations between variables. Our results suggest that researchers need to think more carefully about the ways in which interventions might be used to increase the level of risk taking behavior. Even if risk taking preferences, the decision to start a business and the choice to undertake certain financial investment strategies are (phenotypically) correlated, interventions to increase risk taking preferences may not be likely to increase several of these outcomes, unless the correlations are largely environmental. Because we find that the non-shared environmental portion of the correlation between risk preferences and risk taking choices varies across different risk taking choices, interventions designed to influence general risk preferences should not be expected to affect financial investment choices, stock market participation and occupation choice equally.

\footnotetext{
${ }^{1}$ These results do not indicate that genes determine risk taking behavior - the relationships that we find are nothing more than predispositions. Genes cannot cause people to engage in risky behavior, but they may increase the probability that they will do so.
} 
The paper proceeds as follows. The next section discusses related research. The third describes our empirical research methodology. The fourth section presents our results. The final section discusses the results and provides our conclusions.

\section{Theoretical background}

Some people consistently behave in a risk tolerant manner across various domains (Barsky et al. 1997; Dohmen et al. 2011; Donkers et al. 2001; Dreber et al. 2011; Halek and Eisenhauer 2001; Zhong et al. 2009a, b). Risk-averse individuals tend to avoid risk in their financial investments, occupational choice, and the types of sports and leisure activities they favor, while risk-tolerant individuals tend to accept risk in their financial investments, health, occupational choice, and pastimes (Barsky et al. 1997; Beauchamp et al. 2017; Dohmen et al. 2011; Dreber et al. 2011; Ekelund et al. 2005; Guiso and Paiella 2005; Roe et al. 2009).

The association between risk-taking preferences and choices in different domains could result from genetic factors, environmental factors, or both. For instance, environmental factors, such as life experiences, could lead some people to develop a pattern of taking risks in certain settings. Having developed those behaviors, these people might then become more likely to engage in risky behaviors in other domains. Alternatively, genetic factors could lead some people to develop various types of risk-taking behaviors. For example, genetic predispositions might make some people more comfortable than other people with the human body's reaction to risk, leading them to take risks more often than other people. Finally, the development of risk-taking behavior in multiple domains could be the result of both genetic and environmental influences.

Identifying the source of any correlation between general risk-taking preferences and risk-taking preferences and choices in different domains is important because it affects the ability of scholars to be normative. If the correlation between general risk-taking preferences and risk-taking in different domains is largely environmental, then policy makers might be able to increase the number of people who engage those behaviors by altering the factors that trigger people to develop general risk-taking preferences. For instance, if general risk-taking preferences and risk taking choices in different domains have high environmental correlations, and work conditions affect the development of general risk-taking preferences, then policy makers might seek to boost risk-taking choices in specific domains through interventions to change work conditions.

However, if the correlation between general risk-taking preferences and domainspecific risk taking preferences and choices is largely genetic, then efforts by policy makers to increase the number of people who engage in risk-taking behaviors by altering risk-taking preferences will be less likely to be effective.

Moreover, the way policy makers would increase the number of people who engage in risk taking behavior would be different if the source of the correlation is primarily genetic rather than environmental. Because genetic correlation reflects effects of selection (Johnson et al. 2009), high genetic correlations would imply that policy makers could provide people with individualized environments to help them fully realize their risk-taking behavior in different domains. 
Before researchers can consider whether the correlation between general risk-taking and risk-taking behavior in different domains has a common genetic source, they first need evidence that the behavior in each of the domains has a genetic component. While many factors account for individual differences in risk taking preferences, including demographics, culture, and education (Zhong et al. 2009a, b), prior research has established this precondition. Studies show that preferences for general risk-taking, risky driving, taking risks in leisure activities and sports, health decisions, the tendency to engage in risky occupations like starting businesses and being self-employed, the willingness to purchase stocks, asset allocation within financial portfolios, and preference for investment opportunities with different risk levels all have a genetic component (Barnea et al. 2010; Beauchamp et al. 2017; Cesarini et al. 2009, 2010; Kuhnen and Chiao 2009; Nicolaou et al. 2008; Shane et al. 2010; Simonson and Sela 2011; Zhang et al. 2009; Zhong et al. 2009a, b; Zyphur et al. 2009).

Researchers do not know with certainty the mechanisms through which the genetic effect operates, but they do have hypotheses. Different versions of genes might affect risk-taking by creating variation in physiological attributes that influence the predisposition to engage in high and low risk behavior (Plomin et al. 2013). For instance, some researchers have hypothesized that genetic variation in the neurotransmitter system is a possible channel (Carpenter et al. 2011; Crisan et al. 2009; Dreber et al. 2009; Frydman et al. 2011; Kuhnen and Chiao 2009; Roe et al. 2009; Roiser et al. 2009; Zhong et al. $2009 \mathrm{a}, \mathrm{b})$. When the dompaminergenic reward system is activated by an external stimulus, the body releases the neurotransmitter dopamine, which, in turn, generates a pleasurable feeling.

Human beings have different versions of genes that influence the sensitivity of the body to dopamine uptake. Some people have versions of their dopamine genes that require a higher level of dopamine release to experience the same level of pleasure that other people get from a lower level of release of the neurotransmitter. Some researchers theorize that people with the genetic variants that demand a higher level of dopamine release engage in riskier behaviors to achieve the same pleasurable sensations that people with other genetic variants get from lesser stimulus (Kuhnen and Chiao 2009; Dreber et al. 2009). As a result, these people engage in more risk-taking behavior to trigger the same pleasurable sensations that other people get from lower levels of stimulus (Dreber et al. 2011).

Some people might have an innate biologically-rewarded preference for choosing high-risk high-reward alternatives in multiple behavioral domains, from financial risk taking to occupational choice to health decisions to lifestyle choices, while others might have an innate, biologically-rewarded, preference for choosing low risk-low reward alternatives in all of these domains (Cesarini et al. 2009; Zhong et al. 2009a, b). A common genetic effect might account for both the variation between people and correlation within people across domains in individuals' risk-related behaviors and choices (Simonson and Sela 2011). Those people with the genetic variations that fit high-risk high-return activities tended to have an advantage at undertaking those activities, while those with the genetic variations that fit low-risk, low-return activities tended to have an advantage at undertaking those activities, leading to a fit between genetic composition and behavioral choice (McDermott et al. 2008; Brennan and Lo 2011). 
Based on the above, we examine whether general risk taking preferences and risk taking preferences and choices in different domains have a common genetic source. Specifically, we hypothesize:

Hypothesis 1: General risk preference has a shared genetic aetiology with domainspecific risk preferences.

Hypothesis 2: General risk preference has a shared genetic aetiology with financial investment choices.

Hypothesis 3: General risk preference and the tendency to be an entrepreneur have a shared genetic aetiology.

Hypothesis 4: General risk preference and stock market participation have a shared genetic aetiology.

\section{Methodology}

\subsection{Sample}

Our sample is comprised of 1898 monozygotic (MZ) and 1344 same-sex dizygotic (DZ) twins from the UK who were reared together. ${ }^{2}$ We drew the sample from the TwinsUK registry, one of the largest twin registries available anywhere in the world (Spector and Williams 2006). The subjects are all healthy individuals who completed a questionnaire between December 2010 and May 2011. They are similar to age-matched singletons on multiple dimensions (Andrew et al. 2001).

\subsection{Analyses}

To decompose the variation in human behavior into genetic and environmental components, researchers often compare identical and fraternal twins, as we do here. Data on twins allows us to subdivide correlations between variables into the portion that results from genetic and environmental factors under the equal environments assumption. For this assumption to be violated, environmental factors must treat identical twins more similarly than they treat fraternal twins and this must make a difference in the variable that is being investigated. A number of studies have now confirmed the validity of this assumption (e.g. Scarr and Carter-Saltzman 1979; Kendler et al. 1993; Hettema et al. 1995). Under the equal environments assumptions, behaviors for which the correlation between identical twins is higher than the correlation between fraternal twins show evidence of a genetic component since identical twins share $100 \%$ of their genetic composition, while fraternal twins share, on average, $50 \%$ of their segregating genes.

By comparing identical and fraternal twin correlations between general risk-taking preferences and risk-taking preferences in specific domains, investment choices, the tendency to be an entrepreneur and stock market participation, we can also evaluate the extent to which the correlation between these variables is a function of genetic factors.

\footnotetext{
2 Twin zygosity was established through standard validated questions and through collection of DNA (Peeters et al. 1998; Singer et al. 2005). The sample is primarily female because it was originally designed to examine genetic effects on medical conditions that primarily affect women (e.g., osteoporosis).
} 
(Specifically, we compare one twin's score on a variable with its co-twin's score on another variable.) If the cross-characteristic, cross-twin correlations are higher for identical twins, who are more closely related genetically, than for fraternal twins, then genetic factors contribute to the phenotypic correlation between these attributes. However, if the cross characteristic-cross-twin correlations are no higher for identical twins than fraternal twins, then there is no common genetic component accounting for the correlation of the attributes. That is, the phenotypic correlation is entirely environmental.

Twins have also been utilized to control for unobservable family effects using within-twin-pair estimators. For example, using a sample of Chinese adult twins Chew et al. (2016) find that education decreases the risk aversion towards moderate prospects, moderate hazards and longshot prospects.

\subsection{Measure of general risk preference}

We examine the heritability of risk preference in general by using a question from Dohmen et al. (2011) and Beauchamp et al. (2017). This question asks respondents to indicate on a scale from zero equals "unwilling to take risks" to ten equals "fully prepared to take risks." The question asks: "How do you see yourself? Are you generally a person who is fully prepared to take risks or do you try to avoid taking risks?" We do not treat ordinal scales as having cardinal significance, hence we recoded this variable as a binary variable, with values of 1 for a score above the median response and zero otherwise. ${ }^{3}$

\subsection{Measures of domain-specific risk preferences}

We examine the heritability of five types of domain-specific risk preferences using items from Dohmen et al. (2011): financial matters, car driving, leisure and sports, health, and career. We asked respondents to indicate their willingness to take risks in all five categories on a scale from zero equals "unwilling to take risks" and ten equals "fully prepared to take risks." A factor analysis indicated that the items loaded together (all item loadings exceeded 0.77 and the Eigenvalue of the factor was 3.10). Therefore, we created a scale (Cronbach's alpha equals 0.85) that combines these five items. We also recoded the individual scales as binary variables with values of 1 above the median response and zero otherwise so as not to treat the ordinal domain-specific risk preferences as having cardinal significance.

\subsection{Measures of financial investment choices}

We examine the heritability of financial investment choices by using the following financial investment choice, previously used by Cesarini et al. (2009): "Imagine you have won $£ 100,000$ in a lottery and immediately receive the following financial offer from a reputable bank. If you allow us to invest your money there is a chance that the money will double within two years. It is equally possible that you could lose half of the amount invested. What share of your lottery winnings would you be prepared to

\footnotetext{
${ }^{3}$ We are most grateful to W. Kip Viscusi for this suggestion.
} 
invest in this financially risky, yet lucrative investment: (0) $£ 0,(1) £ 20,000$, (2) $£ 40,000$, (3) £60,000, (4) £80,000, (5) £100,000.”

We also examined the heritability of the following investment choice from Zyphur et al. (2009): “Assume that you have won a 'big prize', but you have to choose among one of three lotteries for your prize. Which of the following would you choose? (please tick only one box): (1) A guaranteed $£ 2,000$ prize; (2) A $50 \%$ chance of receiving $£ 5,000$, and a $50 \%$ chance of receiving nothing; (3) A $20 \%$ chance of receiving $£ 15,000$, and an $80 \%$ chance of receiving nothing."

\subsection{Measures of entrepreneurship}

We measure the tendency to start businesses through two questions commonly used in the entrepreneurship literature (Choi and Shepherd 2004; Delmar and Davidsson 2000; Gartner 1988) and previously used in Nicolaou et al. (2008) to examine the heritability of the tendency to be an entrepreneur. The first asked: "In your working life, how many new businesses, if any, have you started?" The possible responses were: “(0) None, (1) One, (2) Two, (3) Three, (4) Four or more.” The second asked: "In your working life, for how long, if ever, have you been self-employed?" The possible responses were: “(0) Never, (1) 1 or 2 years (2) 3 or 4 years, (3) 5 or 6 years, (4) 7 years or more."

\subsection{Measure of stock market participation}

We examine the heritability of the tendency to invest in the stock market by asking respondents the binary question: "Have you ever made an investment in the stock market?" Our use of this item follows the work of Barnea et al. (2010) who was the first to use it to examine the heritability of stock market participation.

\subsection{Statistical techniques}

We utilized structural equation modelling to examine whether different preferences and choices are heritable, and the extent to which the covariance between them is genetic. ${ }^{4}$ The variance of any phenotype can be partitioned into three (potential) parts: a genetic part (A), a shared environmental part (C), and a unique environmental part (E). Because identical twins share all of their genetic characteristics while fraternal twins share, on average, $50 \%$ of their segregating genes, the correlation between the latent additive genetic factors is constrained at 1 for identical twins and at 0.5 for fraternal twins. The correlation between the latent shared environmental

\footnotetext{
${ }^{4}$ Common method variance, which arises from people's proneness to give responses to the dependent and independent variables that are correlated because of the manner that people reply to questions, can lead to biased results in data from questionnaires (Podsakoff et al. 2003, 2012; Podsakoff and Organ 1986). However, common method variance generally does not affect heritability estimates in twin studies. Studies like ours investigate the cross-twin and cross-characteristic cross-twin correlations between identical and fraternal twins. For common method variance to bias heritability estimates, the manner in which MZ twins reply to the survey questions would have to be different from the manner DZ twins reply to the same questions. In twin data, we see no evidence of this bias.
} 
factors is constrained at 1 for both identical and fraternal twins because all the twins were brought up in the same family.

For each phenotype, we generate a heritability estimate, defined as the proportion of total variation that can be explained by genetic differences. We adjusted for age and sex in all the analyses by undertaking a regression analysis in which the effects of age and sex were partialled out, and heritability estimates were calculated from the adjusted results (Hakim et al. 2004; Mohammed et al. 2003; Neale et al. 2004). We compared a series of nested models to the best fitting model to assess the contribution of the additive genetic, shared environmental, and unique environmental components to the total variance. We selected the best fitting model by using the chi-square test statistic [with a non-significant chi-square indicating a good fit to the data (Betsworth et al. 1994)], the Root Mean Square Error of Approximation (RMSEA) (Neale and Maes 2002), and the Akaike Information Criterion (AIC) (Akaike 1987).

We apply bivariate genetics techniques to examine the cross-characteristic-crosstwin correlations between different preferences and choices. Under the equal environments assumption, greater cross-characteristic-cross-twin correlations between two preferences or choices for identical than for fraternal twins would indicate that genetic factors contribute to the phenotypic correlation between the two variables. The analysis yields the genetic $\left(r_{A}\right)$, shared environmental $\left(r_{C}\right)$ and non-shared environmental $\left(r_{E}\right)$ correlations respectively. ${ }^{5}$

The genetic correlation $\left(\mathrm{r}_{\mathrm{A}}\right)$ measures the degree to which the genetic influences on one variable overlap with those of another, irrespective of the individual heritabilities of the two variables. For example, a genetic correlation of one would imply that all of the genetic influences on general risk-taking preferences overlap with those on financial investment choices.

The shared environmental correlation $\left(\mathrm{r}_{\mathrm{C}}\right)$ measures the extent to which the shared environmental influences on general risk taking preferences are correlated with the shared environmental influences on the other measures (e.g., financial investment choices, the tendency to be an entrepreneur, and so on). The non-shared environmental correlation $\left(\mathrm{r}_{\mathrm{E}}\right)$ captures the unique environmental influences that affect two variables (Plomin et al. 2013). We used the statistical package Mx to fit the structural equation models (Neale et al. 2004).

\section{Results}

Descriptive statistics and correlations are presented in Table 1. This table reveals that risk preferences and choices display significant phenotypic correlations. The presence

\footnotetext{
5 Twin studies rely on the assumption that identical and fraternal twins experience similar shared environments. This equal environments assumption is violated if (i) environmental factors treat identical twins more similarly than they treat fraternal twins and (ii) this differential treatment influences the variables under examination. However, a large number of studies, using a wide range of methods and techniques, have examined the robustness of this assumption, and found it to be valid (Conley and Rauscher 2011; Hettema et al. 1995; Kendler et al. 1993; Kendler and Prescott 2006; Scarr and Carter-Saltzman 1979). Because the validity of the assumption can only be tested on samples of twins that are separated at infancy and reared apart, which are extremely rare and very small in number and do not exist for the topics we examine in this paper, we rely on evidence that the assumption has been found to be valid in previous studies, rather than explicitly test it on this sample.
} 
Table 1 Descriptive Statistics and Correlations

\begin{tabular}{|c|c|c|c|c|c|c|c|c|c|c|c|c|}
\hline Variable & $\mathrm{M}$ & SD & 1 & 2 & 3 & 4 & 5 & 6 & 7 & 8 & 9 & 10 \\
\hline $\begin{array}{l}\text { 1. General risk } \\
\text { preference }\end{array}$ & 0.39 & 0.49 & & & & & & & & & & \\
\hline $\begin{array}{l}\text { 2. Risk in car } \\
\text { driving }\end{array}$ & 0.39 & 0.49 & $.29 * *$ & & & & & & & & & \\
\hline $\begin{array}{l}\text { 3. Financial risk } \\
\text { taking }\end{array}$ & 0.49 & 0.50 & $.33^{* *}$ & $.46^{* *}$ & & & & & & & & \\
\hline $\begin{array}{l}\text { 4. Risk in leisure } \\
\text { and sports }\end{array}$ & 0.44 & 0.50 & $.41 * *$ & $.41 * *$ & $.38 * *$ & & & & & & & \\
\hline $\begin{array}{l}\text { 5. Risk in health } \\
\text { matters }\end{array}$ & 0.45 & 0.50 & $.25^{* *}$ & $.45^{* *}$ & $.45^{* *}$ & $.36^{* *}$ & & & & & & \\
\hline 6. Career risk & 0.44 & 0.50 & $.42 * *$ & $.38 * *$ & $.43 * *$ & $.48 * *$ & $.43 * *$ & & & & & \\
\hline $\begin{array}{l}\text { 7. Investment of } \\
\text { lottery winnings }\end{array}$ & 0.89 & 0.94 & $.18^{* *}$ & $.16^{* *}$ & $.26^{* *}$ & $.19^{* *}$ & $.16^{* *}$ & $.20 *$ & & & & \\
\hline $\begin{array}{l}\text { 8. Higher and lower } \\
\text { risk investments }\end{array}$ & 1.24 & 0.49 & $.16^{* *}$ & $.11 * *$ & $.18 * *$ & $.14^{* *}$ & $.11 * *$ & $.18^{* * *}$ & $.24 * *$ & & & \\
\hline $\begin{array}{l}\text { 9. Stock market } \\
\text { participation }\end{array}$ & 0.55 & 0.57 & $.07 * *$ & .03 & $.11 * *$ & $.05^{* *}$ & .03 & $.06^{* *}$ & $.12 * *$ & $.08^{*}$ & & \\
\hline $\begin{array}{l}\text { 10. Start new } \\
\text { businesses }\end{array}$ & 0.36 & 0.74 & $.14^{* *}$ & $.09 * *$ & $.12 * *$ & $.07 * *$ & $.07 * *$ & $.17 * *$ & $.08 * *$ & $.11 * *$ & $.07 * *$ & \\
\hline $\begin{array}{l}\text { 11. Years } \\
\text { self-employed }\end{array}$ & 0.76 & 1.41 & $.10^{* *}$ & $.05^{* *}$ & $.10^{* *}$ & .03 & .03 & $.11 * *$ & $.08 * *$ & $.07 * *$ & $.10 * *$ & $.59 * *$ \\
\hline
\end{tabular}

Note. ${ }^{* *} p<.01$ (two-tailed test)

of these correlations indicates the value of identifying the degree to which they are the result of genetic and environmental factors.

There were no statistically significant differences between MZ and DZ twins for general risk preferences $(p=0.29)$, the domain-specific risk preference scale $(p=0.14)$, investing in the stock market $(p=0.20)$, the investment of lottery winnings $(p=0.17)$, the choice between higher or lower risk investments $(p=0.26)$, the tendency to start businesses $(p=0.96)$, and years self-employed $(p=0.65)$. Thus, the sample appears unbiased with respect to the distribution of the behaviors we examined across $\mathrm{MZ}$ and DZ twins.

Next, we examined the heritability of the different risk taking preferences and choices. As stated earlier, the heritability of these three dimensions is a necessary condition for genetic factors to account for some of the correlation between them.

We used the chi-square test, the Akaike Information Criterion (AIC) and the Root Mean Square Error of Approximation (RMSEA) to select between the ACE (additive genetic, common environmental and unique environmental), AE (additive genetic and unique environmental) and CE (common environmental and unique environmental) models. Table 2 shows that the best fitting model for general risk preferences involved both additive genetic and unique environmental effects (AE model). We found that 
Table 2 The Heritability of General Risk Preference

\begin{tabular}{lllllllll}
\hline Model & $\mathrm{A}(95 \% \mathrm{CI})$ & $\mathrm{C}(95 \% \mathrm{CI})$ & $\mathrm{E}(95 \% \mathrm{CI})$ & AIC & RMSEA & $X^{2}$ & df & $p$ value \\
\hline $\mathrm{ACE}$ & $0.22(0.09$ to 0.31$)$ & $0(0$ to 0.10$)$ & $0.78(0.69$ to 0.87$)$ & 2.44 & .032 & 8.435 & 3 & 0.04 \\
$\mathrm{CE}$ & - & $0.15(0.07$ to 0.23$)$ & $0.85(0.77$ to 0.93$)$ & 7.72 & .053 & 15.72 & 4 & 0.00 \\
$\mathrm{AE}$ & $0.22(0.13$ to 0.31$)$ & - & $0.78(0.69$ to 0.87$)$ & 0.44 & .027 & 8.435 & 4 & 0.08 \\
\hline
\end{tabular}

Note. A, additive genetic; $\mathrm{C}$, common environment; E, unique environment

general risk preferences had a heritability of 0.22 , with a $95 \%$ confidence interval of 0.12 to 0.28 .

We analyzed the heritability of domain-specific risk preferences both as a five item scale and as individual items. Table 3 shows the results of fitting univariate genetics models for the domain-specific risk preference variables. The five-item scale was heritable, with a heritability of 0.40 . The individual items were also heritable, with heritabilities, ranging from 0.34 to 0.45 . As Table 3 shows, the $95 \%$ confidence intervals for the scale and all five individual items were above zero. The chi-square test, Akaike Information Criterion (AIC) and the Root Mean Square Error of Approximation (RMSEA) showed that the best fitting models involved additive genetic and unique environmental effects (AE model). Shared environmental factors did not account for any of the variance.

We examined the heritability of the investment of lottery winnings and the choice between higher or lower risk investments. Table 4 shows the results of fitting univariate genetics models for the financial choice variables. Both measures of financial choice were heritable, with heritabilities of 0.16 and 0.25 . As Table 4 shows, the $95 \%$ confidence intervals for all three variables were above zero. The chi-square test, Akaike Information Criterion (AIC) and the Root Mean Square Error of Approximation

Table 3 The Heritabilities of the Domain-Specific Risk Preferences

\begin{tabular}{lll}
\hline Variables & $\mathrm{A}$ & $\mathrm{E}$ \\
& $(95 \% \mathrm{CI})$ & $(95 \% \mathrm{CI})$ \\
\hline Risk in financial matters & 0.45 & 0.55 \\
& $(0.36-0.53)$ & $(0.47-0.64)$ \\
Car driving & 0.34 & 0.66 \\
& $(0.25-0.42)$ & $(0.58-0.75)$ \\
Leisure and sport & 0.39 & 0.61 \\
& $(0.30-0.47)$ & $(0.53-0.70)$ \\
Health matters & 0.36 & 0.64 \\
Career & $(0.27-0.45)$ & $(0.56-0.73)$ \\
Domain-specific & 0.36 & 0.64 \\
risk taking scale & $(0.27-0.45)$ & $(0.55-0.73)$ \\
\hline
\end{tabular}

Note. The best fitting model is shown for each variable 
Table 4 The Heritabilities of the Financial Investment Choices and Stock Market Participation

\begin{tabular}{lll}
\hline Variables & $\mathrm{A}$ & $\mathrm{E}$ \\
& $(95 \% \mathrm{CI})$ & $(95 \% \mathrm{CI})$ \\
\hline Investment of lottery winnings & 0.25 & 0.75 \\
& $(0.19-0.30)$ & $(0.70-0.81)$ \\
Higher and lower risk investments & 0.16 & 0.84 \\
Stock market participation & $(0.10-0.21)$ & $(0.79-0.90)$ \\
& 0.37 & 0.63 \\
\end{tabular}

Note. The best fitting model is shown for each variable

(RMSEA) showed that the best fitting model involved additive genetic and unique environmental effects (AE model). Shared environmental factors did not account for any of the variance.

We then analyzed the heritability of stock market participation. The last row of Table 4 shows the results of the best fitting model for this variable, which was the AE model. The heritability estimate was 0.37 with a $95 \%$ confidence interval of 0.32 to $0.43{ }^{6}$

We analyzed the heritability of the tendency to engage in entrepreneurship. For starting a business, we found a heritability of 0.32 , and for years of self-employment we found a heritability of 0.28 . The $95 \%$ confidence interval for starting a business was 0.27 to 0.38 , while for years self-employed it was 0.19 to 0.36 . The chi-square test, Akaike Information Criterion (AIC) and the Root Mean Square Error of Approximation (RMSEA) showed that the best fitting model involved additive genetic and unique environmental effects (AE model). Shared environmental factors did not account for any of the variance.

In short, the first step in our analysis showed a genetic component to general risk preferences, domain-specific risk preferences, financial investment choices, the tendency to be an entrepreneur, and stock market participation.

To assess whether genetic factors account for part of the covariance between general risk preferences and domain-specific risk preferences, and between general risk preferences and risk taking choices, we then fitted bivariate genetics models. Table 5 shows the results of this test.

We focus on the genetic correlation between the variables $\left(\mathrm{r}_{\mathrm{A}}\right)$, and the fraction of the phenotypic correlation between the variables that is explained by genetic factors that are common to the two variables. The genetic correlations ranged from 0.15 to 0.80 . Between 31 and $73 \%$ of the phenotypic correlations between different risk preferences and choices comes from common genetic factors.

Specifically, we found that the genetic correlation between general riskpreferences and domain-specific risk preferences was 0.80 . As one might expect,

\footnotetext{
${ }^{6}$ In the ACE models, the point estimates of the additive genetic (A) and unique environmental factors (E) are identical to the point estimates of the AE models as the point estimates of the common environmental factors (C) are zero (for all variables in Tables 3 and 4).
} 
Table 5 The Genetic Correlations Between the Risk Preferences and Choices

\begin{tabular}{llll}
\hline Bivariate Model & $\mathrm{r}_{\mathrm{A}}$ & $\begin{array}{l}\text { Phenotypic } \\
\text { correlation }\end{array}$ & $\begin{array}{l}\text { Percentage of } \\
\text { correlation due to } \\
\text { genetic } \\
\text { factors }\end{array}$ \\
\hline GRP - Stock market participation & 0.19 & 0.07 & 77 \\
GRP - Investment of lottery winnings & 0.30 & 0.18 & 39 \\
GRP - High and low risk investments & 0.35 & 0.16 & 41 \\
GRP - Domain-specific risk taking scale & 0.80 & 0.61 & 39 \\
GRP - Risk taking in financial matters & 0.41 & 0.33 & 39 \\
GRP - Risk taking in car driving & 0.60 & 0.29 & 57 \\
GRP - Risk taking in leisure and sports & 0.75 & 0.41 & 54 \\
GRP - Risk taking in health matters & 0.40 & 0.25 & 45 \\
GRP - Risk taking in career matters & 0.71 & 0.42 & 48 \\
GRP - Number of businesses started & 0.16 & 0.14 & 30 \\
GRP - Years self-employed & 0.15 & 0.10 & 37 \\
\hline
\end{tabular}

Note. GRP: General risk preference; All phenotypic correlations are significant at $p<0.001$

this genetic correlation is higher than that between general risk preferences and choices that involve risk. The genetic correlations between general risk preferences and investment of lottery winnings and between general risk preferences and the choice of high and low risk investments were 0.30 and 0.35 respectively. The genetic correlations between general risk preferences and stock market participation was 0.19 . Finally, the genetic correlations between general risk preferences and number of businesses started and years self-employed were 0.38 and 0.16 , respectively.

Previous studies (e.g., Nicolaou et al. 2008; Shane et al. 2010) have shown genetic correlations between several psychological characteristics and the tendency to be an entrepreneur. Therefore, we re-ran our bivariate analyses between general risk preferences and the domain-specific risk preferences and the choice variables, controlling for the effects of extraversion, openness to experience, agreeableness, conscientiousness, emotional stability and sensation seeking. We used a sample of 2124 twins (comprised of 547 pairs of MZ and 515 pairs of DZ twins) for which new data from the current survey were linked with old data from previous twin surveys (on the Big Five personality characteristics and sensation seeking). Following previous research (Hakim et al. 2004; Mohammed et al. 2003; Neale 1998), we regressed out the "confounding variables" and estimated genetic correlations on the adjusted results. Our primary results remained robust to this alternative specification.

We also performed a multivariate genetic analysis using a Cholesky decomposition (Gillespie and Martin 2005). In this model, the first variable, general risk preference, is assumed to be caused by a latent factor that also accounts 
for the variance in the remaining variables (stock market participation, the two financial investment choices, entrepreneurship, and the domain-specific risk taking scale), while the second variable, stock market participation, is assumed to be caused by a second latent factor that accounts for the variance in the second as well as the remaining variables. In this way, the second latent factor is restricted from explaining any of the variance in the first variable (general risk preference). This structure continues until the last variable, domain-specific risk taking, which is assumed to be caused by a final latent factor that only accounts for the variance in domain-specific risk taking and is restricted from explaining any of the variance in the previous variables. An additive genetic and non-shared environment (AE) model best explained the sources of covariation between the six factors. The model indicated that of the total additive genetic variance influencing domain-specific risk taking $38 \%$ is specific to this variable and not common with any of the other observed variables.

\section{Discussion}

Although prior research has shown that general risk preferences, domain-specific risk preferences and choices that involve risk are correlated, very little work has investigated whether these correlations were primarily the result of genetic or environmental factors. This study showed that the correlations between general risk preferences, domain-specific risk preferences, financial investment choices, stock market participation, and business formation choices are partially the result of genetic factors.

Human beings may have evolved into different types: Those whose genetic composition predisposes them to high-risk-high-return choices and those whose genetic composition predisposes them to low-risk-low-reward choices. Just as our ancestors chose between hunting and gathering in part because they had innate predispositions toward risk tolerance or risk aversion, today's humans might choose between low-risklow-return and high-risk-high-return occupations and investment strategies.

We posit that the common genetic component to these preferences leads to correlated behaviors among people. Genetic factors account for part of the covariance between general risk preferences and domain-specific risk preferences, between general risk preferences and financial investment choices, between general risk preferences and stock market participation, and between general risk preferences and the choice of entrepreneurship as an occupation. People that are more risk tolerant are more likely to invest in stocks, make riskier financial choices and choose risky occupations, in part, because of the biological processes underlying their behavior.

Our study contributes to a biosocial perspective on risk taking. Domain-specific risk preferences have a non-trivial genetic component. In addition, financial investment choices, the choice to become an entrepreneur, and stock market participation have a sizeable genetic component. These patterns suggest that cross-sectional differences in the preference for risk and risk-taking behavior 
emerge naturally in a society as a function of the distribution of genetic composition (Karlsson Linnèr et al. 2019).

These results have interesting implications for those who examine risk taking. Parent-child similarity in risk taking, a commonly found correlation, may not result from cultural transmission as much as from genetic factors. While our findings do not negate the significance of environmental factors, they show that genetic influences cannot be ignored.

In addition, our results show that all of the environmental influences in risk taking were of the non-shared variety. This suggests that differential experiences outside the family, such as work environment and work colleagues, are more important for risk taking than shared environmental factors such as parental education and shared family rules and upbringing.

Our analysis suggests that a non-trivial fraction of the correlation between risk-taking behaviors results from innate factors. Because the ways to enhance those behaviors vary depending on the levels of genetic and environmental correlations, our results suggest that researchers need to think more carefully about the ways in which interventions might be used to increase the level of risk-taking behavior. Even if variables display a phenotypic correlation, interventions to increase one variable will not be likely to increase the other unless the correlations are largely environmental. Our results showed that a greater fraction of the correlation between general risk-taking preference and stock market participation was genetic than the fraction of the correlation between general risk taking preference and the tendency to be an entrepreneur. Therefore, efforts to increase entry into entrepreneurship by changing risk preferences through education may prove more effective than efforts to increase stock market participation through educationally-induced shifts in general risk preferences.

In addition, our study has implications for molecular genetics research in risk-taking behavior. Because common genetic factors account for a sizeable portion of the correlation between risk-taking preferences and choices in different domains, genes associated with those preferences and choices in one domain are plausible candidate genes for molecular genetics studies of risk-taking preferences and choices in other domains. These genes may also be influential for identifying gene-environment interactions in risk-taking.

It is crucial to stress that our study does not contend that genes determine risk taking behavior. As Johnson et al. (2009) argue, "even highly heritable traits can be strongly manipulated by the environment, so heritability has little if anything to do with controllability" (p. 218). Genes may only predispose some people and not others to develop risk taking preferences and choices. Thus, it is imperative for future research to understand the role that genes play in concert with contextual and environmental factors.

Our study has several limitations. Approximately $92 \%$ of the sample is female, hindering our ability to generalize our results to males. If women are less risk-taking than men, the range of our findings might be restricted when applied to males. While we have no reason to believe that genetic factors would only influence the correlation 
between risk-taking behavior in women and not men, we cannot show the generalizability of our findings across gender either.

Moreover, as in all twin studies, our analysis assumes that there is no assortative mating. Assortative mating - which can arise when individuals have children with individuals who are genetically similar to them-increases the probability that children of similar parents receive more similar gene variants for some attributes than children of "non-similar" parents. Because assortative mating increases the genetic similarity between fraternal twins, but not between identical twins (Guo 2005), it biases the results of twin studies by underestimating the heritability estimates (Plomin et al. 2008). Because we do not know if there is parental assortative mating with respect to risk-taking preferences and choices, we must caution that our findings could be biased downward, and underrepresent the common genetic component to risk-taking.

Furthermore, any violation of the equal environments assumption (EEA) may also affect the robustness of our findings. If environmental factors behave towards identical twins more similarly than towards fraternal twins with respect to risk-taking preferences or choices, the validity of the EEA would be challenged. While we have no reason to believe that this would be the case, we do not have the evidence to empirically verify the validity of the EEA in our study.

In addition, our results may be affected by measurement error. Beauchamp et al. (2017) found that measurement-error-adjusted estimates of heritability were considerably higher than the non-adjusted estimates. They conjecture that "once measurement error is controlled for, the heritability of most economic attitudes will approach that of the 'Big Five' in personality research" (Beauchamp et al. 2017: 231). This suggests that the heritability estimates for our risk taking variables may be conservative.

Finally, our analysis says nothing about the specific genetic mechanism involved in risk taking preferences and choices. Our results are consistent with the proposition that people with different genotypes select into different environments for risk-taking, as well as the proposition that genes themselves have a proximal effect on risk-taking preferences and choices. Moreover, we cannot know from these results what genes are involved in risk-taking preferences and choices or how many genes influence the observed outcomes.

We conclude by strongly encouraging additional research on the genetics of risktaking. Considering the complementary role that biology plays in accounting for risktaking is important lest we limit our ability to explain this important phenomenon. While most social scientists are comfortable exploring the role of environmental factors, they are less comfortable looking at the part that genetics plays. But, as Song, Li, \& Wang (2015) have stressed, the need to account for more of the variance in workrelated behaviour suggests that the role of genetics should be more carefully considered.

Acknowledgments We are most grateful to the editor W. Kip Viscusi, Christina Stoddard, John List, Tim Spector, Juliette Harris, Lynn Cherkas, the anonymous reviewer, and the twins that participated in our study. 


\section{Appendix}

Table 6 Within-Pair Correlations

\begin{tabular}{llc}
\hline Variables & MZ twins & DZ twins \\
\hline Risk in financial matters & 0.47 & 0.24 \\
Car driving & 0.37 & 0.19 \\
Leisure and sport & 0.43 & 0.23 \\
Health matters & 0.40 & 0.21 \\
Investment of lottery winnings & 0.27 & 0.14 \\
Career & 0.40 & 0.21 \\
Higher and lower risk investments & 0.18 & 0.09 \\
Stock market participation & 0.39 & 0.20 \\
\hline
\end{tabular}

Open Access This article is licensed under a Creative Commons Attribution 4.0 International License, which permits use, sharing, adaptation, distribution and reproduction in any medium or format, as long as you give appropriate credit to the original author(s) and the source, provide a link to the Creative Commons licence, and indicate if changes were made. The images or other third party material in this article are included in the article's Creative Commons licence, unless indicated otherwise in a credit line to the material. If material is not included in the article's Creative Commons licence and your intended use is not permitted by statutory regulation or exceeds the permitted use, you will need to obtain permission directly from the copyright holder. To view a copy of this licence, visit http://creativecommons.org/licenses/by/4.0/.

\section{References}

Akaike, H. (1987). Factor analysis and AIC. Psychometrika, 52, 317-332.

Andrew, T., Hart, D. J., Sneider, H., de Lange, M., Spector, T. D., \& MacGregor, A. J. (2001). Are twins and singletons comparable? A study of disease-related and lifestyle characteristics in adult women. Twin Research, 4(6), 464-477.

Barnea, A., Cronqvist, H., \& Siegel, S. (2010). Nature or nurture: What determines investor behavior. Journal of Financial Economics, 98, 583-604.

Barsky, R. B., Juster, F. T., Kimball, M. S., \& Shapiro, M. D. (1997). Preference parameters and behavioral heterogeneity: An experimental approach in the health and retirement study. Quarterly Journal of Economics, 112, 537-579.

Beauchamp, J., Cesarini, D., \& Johannesson, M. (2017). The psychometric and empirical properties of measures of risk preferences. Journal of Risk and Uncertainty, 54, $203-237$.

Betsworth, D., Bouchard, T., Cooper, C., Grotevant, H., Hansen, J., Scarr, S., \& Weinberg, R. (1994). Genetic and environmental influences on vocational interests assessed using adoptive and biological families and twins reared together and apart. Journal of Vocational Behavior, 44, 263-278.

Brennan, T. J., \& Lo, A. W. (2011). The origin of behavior. Quarterly Journal of Finance, 1, 55-108.

Carpenter, J., Garcia, J., \& Lum, J. (2011). Dopamine receptor genes predict risk preferences, time preferences, and related economic choices. Journal of Risk and Uncertainty, 42(3), 233-261.

Cesarini, D., Dawes, C. T., Johannesson, M., Lichtenstein, P., \& Wallace, B. (2009). Genetic variation in preferences for giving and risk taking. Quarterly Journal of Economics, 124, 809-842. 
Cesarini, D., Johannesson, M., Lichtenstein, P., Sandewall, O., \& Wallace, B. (2010). Genetic variation in financial decision making. Journal of Finance, 65(5), 1725-1754.

Chew, S. H., Yi, J., Zhang, J., \& Zhong, S. (2016). Education and anomalies in decision making: Experimental evidence from Chinese adult twins. Journal of Risk and Uncertainty, 53, 163-200.

Choi, Y. R., \& Shepherd, D. A. (2004). Entrepreneurs' decisions to exploit opportunities. Journal of Management, 30(3), 377-395.

Conley, D., \& Rauscher, E. (2011). The equal environments assumption in the post-genomic age: Using misclassified twins to estimate bias in heritability models (NBER working paper No. 16711).

Crisan, LG., Pana, S., Vulturar, R., Heilman, RM., Szekely, R., Druga, B., Dragos, N., Miu, AC. (2009). Genetic contributions of the serotonin transporter to social learning of fear and economic decision making. Social Cognitive and Affective Neuroscience, 4, 399-408.

Delmar, F., \& Davidsson, P. (2000). Where do they come from? Prevalence and characteristics of nascent entrepreneurs. Entrepreneurship Regional Development, 12, 1-23.

Dohmen, T., Falk, A., Huffman, D., Sunde, U., Schupp, J., \& Wagner, G. G. (2011). Individual risk attitudes: Measurement, determinants and behavioral consequences. Journal of the European Economic Association, 9(3), 522-550.

Donkers, B., Melenberg, B., \& van Soest, A. (2001). Estimating risk attitudes using lotteries: A large sample approach. Journal of Risk and Uncertainty, 22(2), 165-195.

Dreber, A., Apicella, C. L., Eisenberg, D. T. A., Garcia, J. R., \& Zamore, R. S. (2009). The 7R polymorphism in the dopamine receptor D4 gene (DRD4) is associated with financial risk-taking in men. Evolution and Human Behavior, 30, 85-92.

Dreber, A., Rand, D. G., Garcia, J. R., Wernerfelt, N., Lum, J. K., \& Zeckhauser, R. (2011). Dopamine and risk preferences in different domains. Journal of Risk and Uncertainty, 43(1), 19-38.

Ekelund, J., Johansson, E., Jarvelin, M. R., \& Lichtermann, D. (2005). Self-employment and risk aversionEvidence from psychological test data. Labour Economics, 12, 649-659.

Frydman, C., Camerer, C., Bossaerts, P., \& Rangel, A. (2011). MAOA-L carriers are better at making optimal financial decisions under risk. Proceedings of the Royal Society B, 278(1714), 2053-2059.

Gartner, W. (1988). Who is an entrepreneur? Is the wrong question. American Journal of Small Business, 12(4), 11-32.

Guiso, L., \& Paiella, M. (2005). The role of risk aversion in predicting individual behavior (Bank of Italy Economic Working Paper No. 546).

Guo, G. (2005). Twin studies: How much can they tell us about nature and nurture? Contexts, 4(3), $43-47$.

Hakim, A. J., Cherkas, L. F., Grahame, R., Spector, T. D., \& MacGregor, A. J. (2004). The genetic epidemiology of joint hypermobility: A population study of female twins. Arthritis and Rheumatism, 50(8), 2640-2644.

Halek, M., \& Eisenhauer, J. G. (2001). Demography of risk aversion. Journal of Risk and Insurance, 68, 1-24.

Hettema, J. M., Neale, M. C., \& Kendler, K. S. (1995). Physical similarity and the equal environment assumption in twin studies of psychiatric disorders. Behavior Genetics, 25(4), 327-335.

Johnson, W., Turkheimer, E., Gottesman, I. I., \& Bouchard, T. J., Jr. (2009). Beyond heritability: Twin studies in behavioral research. Current Directions in Psychological Science, 18(4), 217-220.

Karlsson Linnér, R., Biroli, P., Kong, E., Meddens, S. F. W., Wedow, R., Fontana, M. A., et al. (2019). Genome-wide association analyses of risk tolerance and risky behaviors in over 1 million individuals identify hundreds of loci and shared genetic influences. Nature Genetics, 51(2), 245-257.

Kendler, K. S., \& Prescott, C. A. (2006). Genes, environment and psychopathology. New York: Guilford Press.

Kendler, K. S., Neale, M. C., Kessler, R. C., Heath, A. C., \& Eaves, L. J. (1993). A test of the equal environment assumption in twin studies of psychiatric illness. Behavior Genetics, 23(1), 21-27.

Kuhnen, C. M., \& Chiao, J. Y. (2009). Genetic determinants of financial risk taking. PLoS One, 4(2), e4362.

McDermott, R., Fowler, J., \& Smirnov, O. (2008). On the evolutionary origin of prospect theory preferences. Journal of Politics, 70, 335-350.

Mohammed, I., Cherkas, L. F., Riley, S. A., Spector, T. D., \& Trudgill, N. J. (2003). Genetic influences in gastrooesophageal reflux disease: A twin study. Gut, 52(8), 1085-1089.

Neale, M. C. (1998). Twin analysis. In P. Armitrage \& T. Colton (Eds.), Encyclopedia of biostatistics (pp. 4613-4626). Chichester: Wiley.

Neale, M. C., \& Maes, H. H. M. (2002). Methodology for genetic studies of twins and families. Dordrecht: Kluwer Academic Publishers.

Neale, M. C., Boker, S. M., Xie, G., \& Maes, H. H. M. (2004). Mx software. Richmond: Department of 667 Psychiatry, Virginia Commonwealth University.

Nicolaou, N., Shane, S., Cherkas, L., Hunkin, J., \& Spector, T. D. (2008). Is the tendency to engage in entrepreneurship genetic? Management Science, 54, 167-179. 
Peeters, H., Gestel, S., Vlietinck, R., Derom, C., \& Derom, R. (1998). Validation of a telephone zygosity questionnaire in twins of known zygosity. Behavior Genetics, 28(3), 159-163.

Plomin, R., DeFries, J. C., Knopik, V. S., \& Neiderhiser, J. M. (2013). Behavioral genetics (6th ed.). New York: Worth Publishers.

Podsakoff, P. M., \& Organ, D. W. (1986). Self-reports in organizational research: Problems and prospects. Journal of Management, 12, 69-82.

Podsakoff, P. M., MacKenzie, S. B., Lee, J.-Y., \& Podsakoff, N. P. (2003). Common method biases in behavioral research: A critical review of the literature and recommended remedies. Journal of Applied Psychology, 88(5), 879-903.

Podsakoff, P. M., MacKenzie, S. B., \& Podsakoff, N. P. (2012). Sources of method bias in social science research and recommendations on how to control it. Annual Review of Psychology, 65, 539-569.

Roe, B. E., Tilley, M. R., Gu, H. H., Beversdorf, D. Q., Sadee, W., Haab, T. C., \& Papp, A. C. (2009). Financial and psychological risk attitudes associated with two single nucleotide polymorphisms in the nicotine receptor (CHRNA4) gene. PLoS One, 4(8), e6704. https://doi.org/10.1371/journal.pone.0006704.

Roiser, J. P., de Martino, B., Tan, G. C., Kumaran, D., Seymour, B., Wood, N. W., \& Dolan, R. J. (2009). A genetically mediated bias in decision making driven by failure of amygdala control. Journal of Neuroscience, 29(18), 5985-5991.

Scarr, S., \& Carter-Saltzman, L. (1979). Twin method: Defense of a critical assumption. Behavior Genetics, $9(6), 527-542$.

Shane, S., Nicolaou, N., Cherkas, L., \& Spector, T. (2010). Genetics, the big five and the tendency to be selfemployed. Journal of Applied Psychology, 95(6), 1154-1162.

Simonson, I., \& Sela, A. (2011). On the heritability of consumer decision making: An exploratory approach for studying genetic effects on judgment and choice. Journal of Consumer Research, 7, 951-966.

Singer, J. J., MacGregor, A. J., Cherkas, L. F., \& Spector, T. D. (2005). Where did I leave my keys? A twin study of self-reported memory ratings using the multifactorial memory questionnaire. Twin Research and Human Genetics, 8(2), 108-112.

Song, Z., Li, W., \& Wang, N. (2015). Progress in molecular genetics and its potential implications to OB research. In R. D. Arvey \& S. M. Corlarelli (Eds.), Biological foundations of organizational behavior (pp. 23-46). Chicago: Chicago University Press.

Spector, T. D., \& Williams, F. M. (2006). The UK adult twin registry (TwinsUK). Twin Research and Human Genetics, 9(6), 899-906.

Zhang, Z., Zyphur, M. J., Narayanan, J., Arvey, R. D., Chaturvedi, S., Avolio, B. J., et al. (2009). The genetic basis of entrepreneurship: Effects of gender and personality. Organizational Behavior and Human Decision Processes, 110, 93-107.

Zhong, S., Chew, S.H., Set, E., Zhang, J., Xue, H., et al. (2009a). The heritability of attitude toward economic risk. Twin Research and Human Genetics, 12, 103-107.

Zhong, S., Israel, S., Xue, H., Ebstein, R. P., \& Chew, S. H. (2009b). Monoamine oxidase a gene (MAOA) associated with attitude towards longshot risks. PLoS One, 4(12), e8516.

Zyphur, M. J., Narayanan, J., Arvey, R. D., \& Alexander, G. J. (2009). The genetics of economic risk preferences. Journal of Behavioral Decision Making, 22, 367-377.

Publisher's note Springer Nature remains neutral with regard to jurisdictional claims in published maps and institutional affiliations. 